\title{
Postharvest longevity of 'BRS Vitória' seedless grapes subjected to cold storage and acibenzolar-S-methyl application
}

\author{
Ronan Carlos Colombo(1), Reginaldo Teodoro de Souza(2), Maria Aparecida da Cruz ${ }^{(1)}$, \\ Deived Uilian de Carvalho(1), Renata Koyama(1), Ana Paula Bilck ${ }^{(1)}$ and Sergio Ruffo Roberto ${ }^{(1)}$
}

\begin{abstract}
(1)Universidade Estadual de Londrina, Caixa Postal 10.011, CEP 86057-970 Londrina, PR, Brazil. E-mail: ronancolombo@yahoo.com.br, mary_ac18@hotmail.com, deived10@gmail.com, emykoyama@hotmail.com, ap.bilck@gmail.com, sroberto@uel.br (2)Embrapa Uva e Vinho, Estação Experimental de Viticultura Tropical, Caixa Postal 241, Sítio Embrapa, CEP 15700-000 Jales, SP, Brazil. E-mail: reginaldo.souza@embrapa.br
\end{abstract}

Abstract - The objective of this work was to evaluate cold storage periods and postharvest longevity of the seedless table grape 'BRS Vitória' subjected to the application of the disease-resistance inducer acibenzolarS-methyl (ASM). Bunches were treated or not with 1\% ASM, placed individually in plastic clamshell trays and stored in a cold chamber at $2 \pm 1{ }^{\circ} \mathrm{C}$, at a high relative humidity, for three periods $(30,45$, and 60 days), followed by a 5-day period of shelf life in plastic clamshells, at $22 \pm 2^{\circ} \mathrm{C}$. After each storage period, gray mold (Botrytis cinerea) incidence was evaluated, and the physicochemical analysis was performed. A completely randomized design, with four replicates, was used in two $2 \times 3$ factorial arrangements: one evaluating ASM application and cold storage periods; and another, ASM and cold storage + shelf-life periods. ASM did not change the physicochemical characteristics of the bunches, and the incidence of gray mold was lower than $1 \%$ in all treatments. Water loss from bunches increased with storage periods. Even without ASM application, 'BRS Vitória' grape can preserve its postharvest quality for up to 60 days of cold storage, plus five days of shelf life in plastic clamshells.

Index terms: Botrytis cinerea, Vitis, disease-resistance inducer, gray mold incidence, postharvest conservation, shelf life.

\section{Longevidade pós-colheita da uva sem sementes 'BRS Vitória' submetida a armazenamento a frio e à aplicação de acibenzolar-S-metil}

Resumo - O objetivo deste trabalho foi avaliar períodos de armazenamento em câmara fria e longevidade póscolheita da uva apirena 'BRS Vitória', submetida à aplicação do indutor de resistência a doenças acibenzolarS-metil (ASM). Os cachos foram tratados, ou não, com ASM a 1\%, individualizados em bandejas de plástico e mantidos em câmara fria a $2 \pm 1^{\circ} \mathrm{C}$ e à alta umidade relativa por três períodos (30, 45 e 60 dias), seguidos por cinco dias de avaliação da vida de prateleira, a $22 \pm 2^{\circ} \mathrm{C}$. Após cada período de armazenamento, avaliouse a incidência de mofo-cinzento (Botrytis cinerea), e realizaram-se as análises físico-químicas dos cachos. Utilizou-se o delineamento completamente casualizado, com quatro repetições, em dois arranjos fatoriais 2x3: um com avaliação de ASM e períodos de armazenamento em câmara fria; e outro, de ASM e períodos de armazenamento em câmara fria + vida de prateleira. O ASM não alterou as características físico-químicas dos cachos, e a incidência de mofo-cinzento foi inferior a $1 \%$ em todos os tratamentos. A perda de água dos cachos aumentou com os períodos de armazenamento. Mesmo sem a aplicação de ASM, a uva 'BRS Vitória' pode manter sua qualidade pós-colheita por até 60 dias de armazenamento em câmara fria, além de mais cinco dias de vida de prateleira em bandejas de plástico.

Termos para indexação: Botrytis cinerea, Vitis, indução de resistência a doenças, incidência de mofo-cinzento, conservação pós-colheita, vida de prateleira.

\section{Introduction}

Fortunately, table grapes consumption has increased in the last years, specially the red and black ones, since they are one of the most important sources of phenolic compounds, which are free radicals scavengers (Orak, 2007; Rastija et al., 2009).
The 'BRS Vitória' seedless grape (Vitis spp.), recently released in Brazil, is recommended for cultivation in tropical and subtropical areas, with excellent horticultural performance, high-bud fecundity, and tolerance to downy mildew, the most important disease which affects grapevines in humid subtropical areas. This cultivar of black table grape shows a high yield,

Pesq. agropec. bras., Brasília, v.53, n.7, p.809-814, July 2018 DOI: 10.1590/S0100-204X2018000700004 
greater than $30 \mathrm{Mg} \mathrm{ha}^{-1}$, and it is an excellent option for overseas market because of its firmness and flavor (Maia et al., 2014; Youssef et al., 2015).

However, the market supply of table grapes for larger periods relies on postharvest strategies, such as cold storage, which can extend the maintenance of postharvest quality of the bunches. The storage temperatures and periods depend on the cultivar used, but most commonly they are around $0^{\circ} \mathrm{C}$, with storage periods from 20 to 120 days (Brackmann et al., 2000; Sen \& Kesgin, 2014; Youssef \& Roberto, 2014b; Pinto et al., 2015; Youssef et al., 2015).

Improved methods of packaging, handling, transportation, and marketing can successfully avert huge postharvest losses. Currently, it is very common to observe that most food market chains are equipped with cold chambers for storing fruits and vegetables, before exposing them to commercialization at room temperatures. Moreover, there are several packing material for fruits, but table grapes are usually packaged individually in plastic clamshells, or trays, with 400-500 g net weight, combined with flowpack film, or extruded tubular net, and kept under cold storage in the distribution center, until transportation to the markets.

Other strategies associated to lower temperatures can be used to reduce quality losses and postharvest diseases. Thus, salt treatments with $\mathrm{SO}_{2}$ pads is commonly used (Youssef \& Roberto, 2014a, 2014b; Youssef et al., 2015), or resistance inducers, as acibenzolar-S-methyl (ASM), are applied, in order to reduce the gray mold (Botrytis cinerea) incidence and to improve bunch quality.

Acibenzolar-S-methyl (ASM) is a commercially available plant activator that has been reported to induce plant defense mechanisms for resistance to diseases by activating specific gene expression (Lawton et al., 1996; Pappu et al., 2000). Similarly to salicylic acid, ASM is commonly used as an elicitor of defense against microbial pathogens in agriculture, since it has very low toxicological risk for the environment, in comparison to pesticides used for pest control (Tomlin, 2000; Bi et al., 2007). ASM role as a plant defense activator when applied in pre- or postharvest treatments has been shown in several species, including banana (Zhu et al., 2016), strawberry (Mazaro et al., 2008), melon fruit (Liu et al., 2014), and Sicilian lemon (Panebianco et al., 2014). However, there is a lack of information for the use of ASM associated to different cold storage periods, to improve postharvest longevity of table grapes.

The objective of this work was to evaluate cold storage periods and postharvest longevity of the new seedless table grape 'BRS Vitória' subjected to ASM application.

\section{Materials and Methods}

'BRS Vitória' - resulting from the CNPUV 681-29 [Arkansas 1976 x CNPUV 147-3 ('Niágara Branca' x 'Vênus')] x 'BRS Linda' crossing - table grape bunches were harvest on May, 2016, in a commercial field located in the municipality of Marialva, in the state of Paraná, in Southern Brazil $\left(23^{\circ} 29^{\prime} \mathrm{S}, 51^{\circ} 47^{\prime} \mathrm{W}\right.$, at $570 \mathrm{~m}$ altitude). The vines were grafted onto 'IAC 766 Campinas' rootstock, trained on overhead trellis with $18 \%$ plastic mesh coverage.

The bunches were harvest early in the morning, and selected manually to remove all damaged berries. A completely randomized design was used, with four replicates, in a $2 \times 3$ factorial arrangement with: cold chamber storage periods (30, 45, and 60 days), and ASM application (non-ASM and ASM at $1 \%$ application). The ASM treatment consisted of immersing bunches in ASM solution $1 \%(\mathrm{w} / \mathrm{v})$, for $5 \mathrm{~min}$, while the nontreated bunches were immersed in distilled water for the same period. Then, the bunches were left to dry at room temperature for 1 hour, and placed individually in plastic clamshell trays measuring $21.5 \times 14.0 \times 9.0$ $\mathrm{cm}$. The trays were stored in a cold chamber, for 30 , 45 , or 60 days, at $2 \pm 1^{\circ} \mathrm{C}$ and high relative humidity ( $\mathrm{RH}>90 \%$ ). After the cold storage periods, the bunches were subjected to a 5 -day shelf life test, at $22 \pm 2^{\circ} \mathrm{C}$. The following variables were evaluated at the end of each cold storage period, and after the 5-day shelf life (cold storage + shelf life period): gray mold ( $B$. cinerea) incidence on bunches, expressed as percentage of affected berries $(100 \times$ number of decayed berries/total number of berries), according to Youssef \& Roberto (2014a); water loss (\%), determined after the cold storage and after the cold storage + shelf life periods [water loss $=100 \times$ (initial mass - mass at examined date)/initial mass] (Mattiuz et al., 2009); and berry firmness $(\mathrm{N})$, analyzed after each period with a texture analyzer TA.XT Plus, at the equatorial position in 10 berries (with pedicels) per plot. Each berry was placed 
on the base of the equipment, and compressed using a cylindrical probe with a $35 \mathrm{~mm}$ diameter, parallel to the base. A constant force of $0.1 \mathrm{~N}$, at $1.0 \mathrm{~mm} \mathrm{~s}^{-1}$ speed, was applied to promote the cracking of the sample (Borges et al., 2012).

The bunches were also assessed as to their following chemical characteristics: soluble solids (SS, ${ }^{\circ}$ Brix); titratable acidity (TA, \% of tartaric acid); SS/TA ratio (Roberto et al., 2015); and total anthocyanins content in berry skin [mg of anthocyanins (as malvidin-3glucoside) per gram of skin] (Peppi et al., 2006). Five berries were collected in each box to perform the chemical analysis, totaling 15 berries per plot.

Data were subjected to the analysis of variance, and the means were compared by the Tukey's test, at 5\% probability.

\section{Results and Discussion}

The interaction between cold storage periods and ASM application was not significant for any of the evaluated variables. Moreover, ASM application had no influence on the evaluated variables in 'BRS Vitória' table grape, and differences among treatments were observed only for cold storage and cold storage and shelf life periods.

Gray mold incidence was not observed at the end of the cold storage periods; however, a very low decay $(<1.0 \%$ incidence) was recorded in all treatments at the end of the 5-day shelf life period, without significant differences among treatments (Table 1). Therefore, 'BRS Vitória' seedless grape seems to be tolerant to this postharvest fungal disease, which was also observed by Maia et al. (2014), who reported similar results, when using the cold storage $\left(0^{\circ} \mathrm{C}\right)$ period of 20 days + three days of shelf life exposure, and found no signs of rot.

Although gray mold is a common disease in grapes during postharvest, if the field is free of inoculum, or fungicide treatments are correctly applied at a regular basis, the decay incidence can, in fact, be very low or inexistent. Nonetheless, Youssef \& Roberto (2014a, 2014b) observed natural decay incidence ranging from 5 to $15 \%$ for 'Italia' table grapes, and from 7 to $26 \%$, for 'Benitaka' table grapes, after 30 days of cold storage at $0^{\circ} \mathrm{C}$, followed by seven days of shelf life exposure, at $22^{\circ} \mathrm{C}$. Gray mold can develop in the vineyard and spread rapidly among berries at harvest, and in the period postharvest under cold storage, during long distant transport, and also during the shelf life period (Romanazzi et al., 2012). Sometimes, decay incidence is not observed when bunches are kept under cold storage, but during shelf life, it can reach around 10$20 \%$ incidence, as this is the case for 'Niágara Rosada' grapes kept 21 days under cold storage plus two days at room temperature (Pinto et al., 2015). The onset of these symptoms can occur due to the reduced synthesis of phenolic compounds (for instance, anthocyanins), and to epidermal softening (Pezet et al., 2003).

As to water loss, berry firmness, and total anthocyanins content, significant differences were observed among treatments. The longer the cold storage period, the greater the weight loss due to water loss, which reached around $10 \%$ when bunches were stored for 60 days (Table 1). After the additional 5-day shelf life period, the weight loss was around 3.0\%. The weight loss depends on the grape cultivar used, harvest conditions, cold-chamber temperature, storage period, package type, among other factors. Weight loss of $4.8 \%$ was observed for 'Crimson Seedless' grapes stored at $0^{\circ} \mathrm{C}$ for 60 days (Samra, 2015), and of $6.5 \%$ for 'Bidaneh Sefid' grapes stored for 45 days at $0^{\circ} \mathrm{C}$ (Ranjbaran et al., 2011).

Table 1. Gray mold incidence, water loss, and berry firmness in 'BRS Vitória' seedless table grape subjected to different cold storage, or to different cold storage + shelf life periods and acibenzolar-S-methyl (ASM) application ${ }^{(1)}$.

\begin{tabular}{|c|c|c|c|}
\hline Variable & $\begin{array}{c}\text { Gray mold } \\
(\%)\end{array}$ & $\begin{array}{c}\text { Water loss } \\
(\%)\end{array}$ & $\begin{array}{l}\text { Berry firmness } \\
(\mathrm{N})\end{array}$ \\
\hline & \multicolumn{3}{|c|}{ Cold storage } \\
\hline 30 days & 0.48 & $6.82 \mathrm{~b}$ & $8.90 \mathrm{a}$ \\
\hline 45 days & 0.48 & $8.43 \mathrm{ab}$ & $8.55 \mathrm{ab}$ \\
\hline 60 days & 0.43 & $9.84 \mathrm{a}$ & $7.60 \mathrm{~b}$ \\
\hline \multicolumn{4}{|l|}{ ASM application } \\
\hline Non-ASM & 0.35 & 8.17 & 8.12 \\
\hline ASM $1 \%$ & 0.58 & 8.56 & 8.09 \\
\hline $\mathrm{CV}(\%)$ & 44.57 & 26.80 & 12.57 \\
\hline & \multicolumn{3}{|c|}{ Cold storage + shelf life } \\
\hline $30+5$ days & 0.85 & $0.93 \mathrm{c}$ & 8.38 \\
\hline $45+5$ days & 0.75 & $2.52 \mathrm{~b}$ & 7.81 \\
\hline $60+5$ days & 0.98 & $3.15 \mathrm{a}$ & 7.59 \\
\hline \multicolumn{4}{|l|}{ ASM application } \\
\hline Non-ASM & 0.91 & 2.13 & 8.25 \\
\hline ASM $1 \%$ & 0.80 & 2.27 & 8.11 \\
\hline CV (\%) & 51.51 & 16.13 & 9.58 \\
\hline
\end{tabular}

${ }^{(1)}$ Means followed by equal letters do not differ significantly by Tukey's test, at $5 \%$ probability. 
The loss of water can reduce berry firmness, among other factors, as observed for grapes at the end of each cold storage period (Table 1). The longer the cold storage period (60 days), the lower the berry firmness $(7.60 \mathrm{~N})$, which was also observed by Ranjbaran et al. (2011), El-Metwally et al. (2014), Samra et al. (2014), and Samra (2015). 'BRS Vitória' has a crunchy taste, and the loss of berry firmness is not a desirable trait; however, in the present study, the losses were inexpressive up to 45 days of cold storage, and of small magnitude even after 60 days of cold storage, with, or without the extended period of shelf life. This preserved the crunchy taste of the berries.

After 30 or 45 days of cold storage, the anthocyanin contents were higher (Table 2) than those of recently harvested grapes $\left(8.88 \mathrm{mg} \mathrm{g}^{-1}\right)$, a fact that could be related to the previously reported loss of weight, which might have concentrated these compounds in the berry skin. However, it was clear that the content of anthocyanins decreased after 60 days of cold storage. It is possible that anthocyanin degradation might have become more significant after 45 days. Concellón et al. (2007) reported similar loss of red color in eggplants (Solanum melongena) subjected to chilling injury

Table 2. Soluble solids (SS), titratable acidity (TA), SS/ TA ratio, and total anthocyanins content (ANT) in 'BRS Vitória' seedless table grape subjected to different cold storage, or to different cold storage + shelf life periods and acibenzolar-S-methyl (ASM) application ${ }^{(1)}$.

\begin{tabular}{|c|c|c|c|c|}
\hline Variable & SS ( $\left({ }^{\circ}\right.$ Brix $)$ & TA $(\%)$ & SS/TA & $\operatorname{ANT}\left(\mathrm{mg} \mathrm{g}^{-1}\right)$ \\
\hline & \multicolumn{4}{|c|}{ Cold storage } \\
\hline 30 days & 16.49 & 0.74 & 21.92 & $11.72 b$ \\
\hline 45 days & 16.51 & 0.79 & 20.96 & $13.41 \mathrm{a}$ \\
\hline 60 days & 16.24 & 0.75 & 21.85 & $8.29 \mathrm{c}$ \\
\hline \multicolumn{5}{|c|}{ ASM application } \\
\hline Non-ASM & 16.33 & 0.75 & 21.93 & 11.39 \\
\hline ASM $1 \%$ & 16.23 & 0.77 & 21.22 & 10.89 \\
\hline \multirow[t]{2}{*}{$\mathrm{CV}(\%)$} & 3.83 & 7.88 & 11.15 & 11.84 \\
\hline & \multicolumn{4}{|c|}{ Cold storage + shelf life } \\
\hline $30+5$ days & 16.10 & 0.70 & 23.71 & $11.47 \mathrm{a}$ \\
\hline $45+5$ days & 16.14 & 0.77 & 21.08 & $12.24 \mathrm{a}$ \\
\hline $60+5$ days & 15.90 & 0.71 & 22.48 & $8.43 \mathrm{~b}$ \\
\hline \multicolumn{5}{|c|}{ ASM application } \\
\hline Non-ASM & 16.13 & 0.73 & 22.14 & 10.75 \\
\hline ASM 1\% & 16.22 & 0.72 & 22.70 & 10.67 \\
\hline CV (\%) & 4.77 & 6.88 & 10.34 & 9.15 \\
\hline
\end{tabular}

${ }^{(1)}$ Means followed by equal letters do not differ by the Tukey's test, at $5 \%$ probability. $\left(0^{\circ} \mathrm{C}\right)$, in which browning with concomitant vacuolar disruption, electrolyte leakage, $\mathrm{pH}$ increase, and anthocyanin decrease were observed in the fruit skin.

The contents of soluble solids observed at the end of each cold storage period $\left(>16.0^{\circ}\right.$ Brix) were higher than those at harvest $\left(15.3^{\circ} \mathrm{Brix}\right)$, even though cold storage and ASM had no effect on the remaining chemical characteristics of bunches (Table 2). As grapes are nonclimacteric fruit, there is low consumption of sugar for respiration during the postharvest life (Ranjbaran et al., 2011), and this increased brix value can be related to the weight loss observed during storage. Neither did titratable acidity nor the SS/ TA ratios differ significantly among all treatments; however, after the cold storage periods, bunches had their titratable acidity decreased from $1.0-0.7 \%$, and their SS/TA ratio increased from 15.5 to above $20.0 \%$.

Berry acidity decreases quickly after the beginning of "verasion" and, during ripening, it takes a more gradual pace. This process continues during the postharvest because some organic acids are degraded in the respiration process (Keller, 2015). Thereby, the SS/TA ratio observed at the end of the shelf life was higher than the observed at the end of cold storage periods. For the marketing of table grapes, it is recommended for most cultivars a SS/TA ratio higher than 20 (Gayet, 1993).

Regarding ASM application, many reports indicate that this resistance inducer can effectively controll gray mold and other postharvest diseases in apple, banana, strawberry, melon, and Sicilian lemon (Mazaro et al., 2008; Muñoz \& Moret, 2010; Alamino et al., 2013; Liu et al., 2014; Panebianco et al., 2014; Zhu et al., 2016). In the present work, however, natural gray mold incidence was very low, and the ASM effect against it was impossible to assess. Nonetheless, ASM application did not alter the physicochemical characteristics of the grapes, as observed for 'Aromas' strawberry, in which Mazaro et al. (2008) did not observe changes as for weight loss and SS contents due to ASM applications in the preharvest period.

In addition, grape packaging with low-density materials, such as clamshell trays, has also been shown as an efficient alternative for the preservation of quality for longer periods, besides serving as a physical barrier for contaminant agents and water losses (Ferri et al., 2004; Camargo et al., 2012). Moreover, the use of individual plastic clamshells reduces bunch 
manipulation, avoiding further damages and quality losses on fruit.

Therefore, 'BRS Vitória' packing in plastic clamshells under cold storage provides high longevity of grapes, for up to 60 days, even though water loss from bunches increases over time, reaching around $10 \%$ at this period, and another 3\% after the 5-day shelf life period. The berries, nonetheless, maintain good physicochemical properties all along the storage and shelf life periods.

\section{Conclusion}

Even without ASM application, 'BRS Vitória' grape (Vitis spp.) can preserve its postharvest quality for up to 60 days of cold storage at $2^{\circ} \mathrm{C}$, plus five days of shelf life in plastic clamshells at $22^{\circ} \mathrm{C}$.

\section{Acknowledgments}

ToConselho Nacionalde Desenvolvimento Científico e Tecnológico (CNPq, process number 140588/2015-9) and to Coordenação de Aperfeiçoamento de Pessoal de Nível Superior (Capes), for scholarships.

\section{References}

ALAMINO, D.A.; CABRAL, V.B.; DANNER, M.A.; MARCHESE, J.A. Indução de resistência à podridão-amarga em maçãs pelo uso de eliciadores em pós-colheita. Pesquisa Agropecuária Brasileira, v.48, p.249-254, 2013. DOI: 10.1590/ S0100-204X2013000300002.

BI, Y.; LI, Y.; GE, Y. Induced resistance in postharvest fruits and vegetables by chemicals and its mechanism. Stewart Postharvest Review, v.6, p.1-7, 2007. DOI: 10.2212/spr.2007.6.1.

BORGES, R. de S.; ROBERTO, S.R.; YAMASHITA, F.; OLIVATO, J.B.; ASSIS, A.M. de. Sensibilidade ao rachamento de bagas das videiras 'Concord', 'Isabel' e 'BRS Rúbea'. Revista Brasileira de Fruticultura, v.34, p.814-822, 2012. DOI: 10.1590/ S0100-29452012000300022.

BRACKMANN, A.; MAZARO, S.M.; WACLAWOVSKY, A.J. Armazenamento refrigerado de uvas Cvs. Tardia de Caxias e Dona Zilá. Ciência Rural, v.30, p.581-586, 2000. DOI: 10.1590/ S0103-84782000000400004.

CAMARGO, R.B.; TERAO, D.; PEIXOTO, A.R.; ONO, E.O.; CAVALCANTI, L.S.; COSTA, R.M. da. Atmosfera modificada na conservação da qualidade de uva 'Thompson Seedless' e na redução da podridão de Aspergillus. Summa Phytopathologica, v.38, p.216-222, 2012. DOI: 10.1590/S0100-54052012000300006.

CONCELlÓN, A.; AÑÓN, M.C.; CHAVES, A.R. Effect of low temperature storage on physical and physiological characteristics of eggplant fruit (Solanum melongena L.). Food Science and Technology, v.40, p.389-396, 2007. DOI: 10.1016/j. lwt.2006.02.004.

EL-METWALLY, M.A.; TARABIH, M.E.; EL-ERYAN, E.E. Effect of application of application of $\beta$-aminobutyric acid on maintaining quality of Crimson Seedless grape and controlling postharvest diseases under cold storage conditions. Plant Pathology, v.13, p.139-151, 2014. DOI: 10.3923/ppj.2014.139.151.

FERRI, V.C.; RINALDI, M.M.; DANIELI, R.; LUCCHETTA, L. ROMBALDI, C.V. Atmosfera modificada na conservação de caquis (Diospyrus kaki, L) cultivar Fuyu. Revista Brasileira de Agrociência, v.10, p.111-115, 2004.

GAYET, J.P. Características das frutas de exportação. In: GORGATTI NETTO, A.; GAYET, J.P.; BLEINROTH, E.W.; MATALLO, M.; GARCIA, E.; GARCIA, A.E.; ARDITO, E.F.G.; BORDIN, M. Uva para exportação: procedimentos de colheita e pós-colheita. Brasília: Embrapa-SPI, 1993. p.9-11. (Publicações técnicas Frupex, 2).

KELLER, M. The science of grapevines: anatomy and physiology. $2^{\text {nd }}$ ed. Amsterdam: Elsevier, 2015. 509p.

LAWTON, K.A.; FRIEDRICH, L.; HUNT, M.; WEYMANN, K.; DELANEY, T.; KESSMANN, H.; STAUB, T.; RYALS, J. Benzothiadiazole induces disease resistance in Arabidopsis by activation of the systemic acquired resistance signal transduction pathway. Plant Journal, v.10, p.71-82, 1996. DOI: 10.1046/j.1365313X.1996.10010071.x.

LIU, Y.; GE, Y.; BI, Y.; LI, C.; DENG, H.; DONG, B. Effect of postharvest acibenzolar-S-methyl dipping on phenylpropanoid pathway metabolism in muskmelon (Cucumis melo L.) fruits. Scientia Horticulturae, v.168, p.113-119, 2014. DOI: 10.1016/j. scienta.2014.01.030.

MAIA, J.D.G.; RITSCHEL, P.; CAMARGO, U.A.; SOUZA, R.T. de; FAJARDO, T.V.M.; NAVES, R. de L.; GIRARDI, C.L. 'BRS Vitória' - a novel seedless table grape cultivar exhibiting special flavor and tolerance to downy mildew (Pasmopara viticola). Crop Breeding and Applied Biotechnology, v.14, p.204-206, 2014. DOI: $10.1590 / 1984-70332014 v 14 n 3 a 31$.

MATTIUZ, B.-H.; MIGUEL, A.C.A.; GALATI, V.C.; NACHTIGAL, J.C. Efeito da temperatura no armazenamento de uvas apirênicas minimamente processadas. Revista Brasileira de Fruticultura, v.31, p.44-52, 2009. DOI: 10.1590/S010029452009000100008.

MAZARO, S.M.; DESCHAMPS, C.; MAY DE MIO, L.L.; BIASI, L.A.; GOUVEA, A. de; SAUTTER, C.K. Comportamento pós-colheita de frutos de morangueiro após a aplicação précolheita de quitosana e acibenzolar-S-metil. Revista Brasileira de Fruticultura, v.30, p.185-190, 2008. DOI: 10.1590/S010029452008000100034.

MUÑOZ, Z.; MORET A. Sensitivity of Botrytis cinerea to chitosan and acibenzolar-S-methyl. Pest Management Science, v.66, p.974-979, 2010. DOI: 10.1002/ps.1969.

ORAK, H.H. Total antioxidant activities, phenolics, anthocyanins, polyphenoloxidase activities of selected red grape cultivars and their correlations. Scientia Horticulturae, v.111, p.235-241, 2007. DOI: $10.1016 /$ j.scienta.2006.10.019. 
PANEBIANCO, S.; VITALE, A.; PLATANIA, C.; RESTUCCIA, C.; POLIZZI G.; CIRVILlERI, G. Postharvest efficacy of resistance inducers for the control of green mold on important Sicilian citrus varieties. Journal of Plant Diseases and Protection, v.121, p.177-183, 2014. DOI: 10.1007/BF03356507.

PAPPU, H.R.; CSINOS, A.S.; MCPHERSON, R.M.; JONES, D.C.; STEPHENSON, M.G. Effect of acibenzolar-S-methyl and imidacloprid on suppression of tomato spotted wilt Tospovirus in flue-cured tobacco. Crop Protection, v.19, p.349-354, 2000. DOI: 10.1016/S0261-2194(00)00028-4.

PEPPI, M.C.; FIDELIBUS, M.W.; DOKOOZLIAN, N. Abscisic acid application timing and concentration affect firmness, pigmentation, and color of 'Flame Seedless' grapes. HortScience, v.41, p.1440-1445, 2006.

PEZET, R.; PERRET, C.; JEAN-DENIS, J.B.; TABACCHI, R.; GINDRO, K.; VIRET, O. $\delta$-Viniferin, a resveratrol dehydrodimer: one of the major stilbenes synthesized by stressed grapevine leaves. Journal of Agricultural and Food Chemistry, v.51, p.5488-5492, 2003. DOI: 10.1021/jf030227o.

PINTO, J.A.V.; SCHORR, M.R.W.; THEWES, F.R.; CECONI, D.L.; BOTH, V.; BRACKMANN, A.; FRONZA, D. Relative humidity during cold storage on postharvest quality of 'Niagara Rosada' table grapes. Ciência Rural, v.45, p.386-391, 2015. DOI: 10.1590/0103-8478cr20130307.

RANJBARAN, E.; SARIKHANI, H.; WAKANA, A.; BAKHSHI, D. Effect of salicylic acid on storage life and postharvest quality of grape (Vitis vinifera L. cv. Bidaneh Sefid). Journal of the Faculty of Agriculture, Kyushu University, v.56, p.263-269, 2011.

RASTIJA, V.; SRECNIK, G.; MARICA-MEDIĆ-ŠARIĆ. Polyphenolic composition of Croatian wines with different geographical origins. Food Chemistry, v.115, p.54-60, 2009.

ROBERTO, S. R.; BORGES, W. F. S.; COLOMBO, R. C.; KOYAMA, R.; HUSSAIN, I.; SOUZA, R. T. Berry-cluster thinning to prevent bunch compactness of 'BRS Vitoria', a new black seedless grape. Scientia Horticulturae, v.197, p.297-303, 2015.
ROMANAZZI, G.; LICHTER, A.; GABLER, F.M.; SMILANICK, J.L. Recent advances on the use of natural and safe alternatives to conventional methods to control postharvest gray mold of table grapes. Postharvest Biology and Technology, v.63, p.141-147, 2012. DOI: 10.1016/j.postharvbio.2011.06.013.

SAMRA, B.N. Impact of postharvest salicylic acid and jasmonic acid treatments on quality of 'Crimson Seedless' grapes during cold storage and shelf life. International Journal of Advanced Research, v.3, p.483-490, 2015.

SAMRA, B.N.; NAGATY, M.A.; FAHMI, A.I. Storage studies on clusters of Taify table grape. Life Science Journal, v.11, p.319326, 2014.

SEN, F; KESGIN, M. Effect of different covering materials used during the pre-harvest stage on the quality and storage life of 'Sultana Seedless' grapes. Food Science and Technology, v.34, p.787-792, 2014. DOI: 10.1590/1678-457X.6484.

TOMLIN, C.D.S. The pesticide manual. $12^{\text {th }} \mathrm{ed}$. London: British Crop Protection Council, 2000.

YOUSSEF, K.; ROBERTO, S.R. Applications of salt solutions before and after harvest affect the quality and incidence of postharvest gray mold of 'Italia' table grapes. Postharvest Biology and Technology, v.87, p.95-102, 2014a. DOI: 10.1016/j. postharvbio.2013.08.011.

YOUSSEF, K.; ROBERTO, S.R.; CHIAROTTI, F.; KOYAMA, R.; HUSSAIN, I.; SOUZA, R.T. de. Control of Botrytis mold of the new seedless grape 'BRS Vitoria' during cold storage. Scientia Horticulturae, v.193, p.316-321, 2015. DOI: 10.1016/j. scienta.2015.07.026.

YOUSSEF, K.; ROBERTO, S.R. Salt strategies to control Botrytis mold of 'Benitaka' table grapes and to maintain fruit quality during storage. Postharvest Biology and Technology, v.95, p.95102, 2014b. DOI: 10.1016/j.postharvbio.2014.04.009.

ZHU, X.; LIN, H.; SI, Z.; XIA, Y.; CHEN, W.; LI, X. Benzothiadiazole-mediated induced resistance to Colletotrichum musae and delayed ripening of harvested banana fruit. Journal of Agricultural and Food Chemistry, v.64, p.1494-1502, 2016. DOI: $10.1021 /$ acs.jafc.5b05655.

Received on March 24, 2017 and accepted on October 9, 2017 